UDC 343.919

CERIF: H220, S100, S110, S142

\author{
Melina Rokai, PhD*
}

\title{
IMPOSSIBLE ESCAPE: INQUISITOR JACQUES FOURNIER AND THE TRIALS OF THE CATHARS AT THE END OF THEIR EXISTENCE IN LANGUEDOC
}

Analyses of cases contained in the Register of inquisitor Jacques Fournier (1318-1325) allude to the difficulty of a suspect leaving the inquisitorial trial without a sentence in the form of penitence. Having in mind the sentiments of contemporaries regarding the trials and the current multidisciplinary scholarship on the subject, the author investigates the changes Fournier that made in the system, through analysis of three cases least-related to heretical dogma. The author came to the conclusion that: 1) early centralization of medieval France facilitated alterations of the inquisitorial process, 2) the inquisition started regarding heretical certain deeds (and often even thoughts) that had previously not been considered heretical, by linking simple unacceptable behaviour to elements of heretical beliefs.

Key words: Inquisitorial trials. - Jacques Fournier. - Catharism. - France.

\section{INTRODUCTION}

Jacque Fournier, the Bishop of Pamiers, commenced inquisitorial career against the heretics in southern France when the region's largest heretical movement was fading. At the beginning of the fourteenth century, Catharism held a fraction of the power that it represented before Montsegur fell and the bloom of the movement had passed. Fournier dealt the last blow to Catharism through zealous inquisitorial processes against all elements that might have resembled Cathar teaching. The ex-

* Research Associate on project Modernization of the Western Balkans financed by the Ministry of Science, Education and Technological Development of Republic of Serbia, No.177009, melinarokai85@hotmail.com. The paper is the result of research on the same project. 
tinction of Catharism in Languedoc is causally related to the observation that it was almost impossible for an accused, who was supposed to 'talk' and 'confess' about himself and others, to leave the inquisitorial process without a sentence. This was also influenced by changes in the system of the French inquisition in the early $14^{\text {th }}$ century. This was truer for the elements connected to the inquisitorial process, which in its nature was a court process.

Although the majority of historians studying late Catharism in Languedoc believe that medieval inquisition was not particularly bloody, ${ }^{1}$ sentences were unproportionally tough and once the accused entered the system it was impossible for them to leave without penitence, which had the characteristics of a sanction.

In order to illustrate and analyse the issue convincingly, the paper will consider particularities of Fournier's inquisitorial procedure. With the aim of a better contextualization, the paper will consider features of the inquisitorial process and examine inquisitorial texts, which influenced the formation of the very procedures and the construction of the heretical identity. The issue will be presented in the paper through the analysis of three case studies from Fournier's Register, which covers the period from 1318 to 1325 . The chosen cases have the least connection to the Cathar teachings or other dogmas, which the Catholic Church deemed heretical. It needs to be acknowledged that Michel Foucault's methodological approach in construction of the 'other', and his discourse on the relationship between power and knowledge, is featured in the works of several recent historians of Catharism. ${ }^{2}$

\section{THE INQUISITION AND INQUISITORIAL TRIBUNALS IN LANGUEDOC AND THEIR PRACTICE}

It needs to be mentioned that there was no single inquisition headed by the Great Inquisitor in the Middle Ages. The inquisition in Medieval France consisted of a number of tribunals, led by the Franciscans or Dominicans, or by local bishops, as it was the case with a tribunal of Pamiers, where Jacques Fournier was the bishop. Regardless of the lack of the institutionalized inquisition, all tribunals shared certain features: the inquisitors were directly responsible to the Pope; they commenced the trials ex-officio against those who were either accused of heresy or the inquisitors suspected them of heresy; processes were secret, just as were

1 J. Given, "The Inquisitors of Languedoc and the Medieval Technology of Power", The American Historical Review 94(2)/1989, 353; J. Given, Inquisition and Medieval Society. Power, Discipline, and Resistance in Languedoc, Ithaka, 1997, 66-90.

2 R. I. The Formation of a Persecuting Society, Oxford 2007. 
the identities of those who testified against the accused; and finally, the condemned person could not appeal the inquisitors' decision. ${ }^{3}$ It is generally accepted that the accused had no right to counsel, which can be found in Practica, the manual created by inquisitor Bernard Gui, where it is stated that "the inquisitor can commence... without lawyers' supervision". ${ }^{4}$ Jean Duvernoy claims that there were exceptions when lawyers were present, although he concedes that their presence was not of tremendous significance to the victims of the inquisition. ${ }^{5}$ The inquisitorial process was also made easier when at the end of the $12^{\text {th }}$ century procedure replaced accusation. Furthermore, by this time the inquisitorial procedure had become part of the church courts, which enabled the judge to take action against those suspected only on the basis of rumors.

The Dominicans established two inquisitorial tribunals in Languedoc: one in Toulouse and another in Carcassonne, which was assisted by the bishop tribunals in Carcassonne, Albi, and Pamiers.

The facilitation of inquisitorial procedures, their strengthening, as well as eventual transformation and alteration, needs to be understood as a method used by the political authorities to legitimize themselves at the times of preliminary centralization, manifested in the development of the state system during the period of the High Middle Ages.

The French inquisition invented new ways of manipulating its subjects. James Given offered a detailed analysis of techniques, which were used by the inquisitors in Languedoc in the suppression of heresy, both of those taken from the state authorities and those organic to the Catholic Church, developed over centuries of fighting the heretics. Among these, prisons should be mentioned here, which were employed frequently as punishment, since Church institutions were not allowed to order 'spilling of blood'. The reality that this observation is more than the fruit of historians' construction is apparent from the fact that one of the three most important inquisitors in Languedoc, Bernard Gui, in his Practica, advised his collegues that a stay of several years in prison led even the most headstrong to confess. In addition to the fact that a long stay in prison affected the accused in a psychological manner, due to the isolation element, the psychological pressure could be further manipulated by denying prisoner food and putting him in the shackles, which would further restrict their already limited mobility. ${ }^{6}$ Given emphasizes the creation of inquisitorial

3 See: E. Griffe, Le Languedoc Cathare et l'Inquisition 1229-1329, Paris 1980.

4 B. Guidonis, Practica inquisitionis heretice pravitatis auctore Bernardo Guidonis (ed. C. Douais), Paris 1886, 192.

5 J. Duvernoy, "La Procedure de Repression de l'Heresie en Occident au MoyenAge", Heresis 6/1986, 50.

6 B. Gui, Manuel de l'inquisitor, 1-2 vols. (ed. and trans. G. Mollat), Paris 7/1926, 1, 182-3. 
registers, which document and follow all idiosyncracies in confessions, and which were used for future reference. The very existence of the registers of the inquisitional processes, as well as the manner of their use, became the objects of knowledge, which further empowered the system of the inquisition.

The amalgamation of the techniques employed by the inquisitors, which was founded on the interdependence of knowledge of the 'object' of the inquisitorial trial and power over it, found their expression in the construction of the heretic and creation of an appropriate reality. James Given and John Arnold employed the idea of the construction of the 'other' in their studies of the functioning of the inquisition in Languedoc.

\section{A HARLOT, A SODOMITE AND A REACTIONARY TO THE CHANGES IN THE FEUDAL SYSTEM}

This part of the paper analyses three case studies from Jacques Fournier's Register in order to demonstrate the impossibility of remaining unpunished, as well as why the weight of punishment seemed unfair to contemporaries and disproportionate to historians. The chosen cases are the least connected to the idea of the Cathar teachings i.e. the deponents in these cases offered the least material linked to activities which, up until Jacques Fournier's time, had been considered heretical. ${ }^{8}$

It should be mentioned that the construction of 'the heretical identity' did not start with Fournier and his inquisitorial work. The idea of those who could be considered heretics had been constructed in the period of a couple of centuries during which the Catholic Church in the south of France fought against the Cathar movement. The Church desired to know the exact beliefs which were held by the heretics and what were the points in which it deviated from the orthodoxy. With this in mind, the Manuals were created, which defined actions and relations that were taken to be heretical. A great majority of the society was acquainted with the construction and their possible defence in the trials was founded on this knowledge. One of the main actions for which an accused could be sentenced for penitence was 'seeing' prefect. A number of other actions followed this one, such as assisting the Cathars materially, sheltering them, 59.

7 J. Given (1989), 343-347; J. Paul, “Jacques Fournier inquisiteur”, CdF 26/1991,

8 The edited publication of Fournier's Register in Latin by Jean Duvernoy was used in this paper: Le Registre d'inquisition de Jacques Fournier, évêque de Pamiers, 1318-1325: manuscrit Vat. latin $n^{o} 4030$ de la Bibliothèque vaticane, par J. Duvernoy, Toulouse 3/1965(in ft.: Fournier), whilst the years follow our contemporary calendar, as dated in the French translation of the Register, as this is the common practice. 
giving them directions, performing actions that meant becoming a Cathar, or as they called themselves "Ggood Men" (and women).

It is with Fournier's inquisitorial practice that a change in the construction of a heretic was noticed. Deponents mentioned in the Register were required to confess their heresy or that of anyone they might have known. John Arnold states that by confessing to the heresy, the accused were called upon to confess other types of transgressions, such as those that could have been considered as sexual and gender deviations. While discussing about the construction of the confessing subject, Arnold further stresses that the deponents were not only confessing to heresy, their own or someone else's, but also "sexual subjects, gender subjects, social subject," etc. ${ }^{9}$ I would add to this study of the literary construction of the object, which is based on Michel Foucault's idea, that both sexual and elements of social order were in practice a part of the religious state of affairs, and as such were frequently regulated by ecclesiastical institutions. Thus, Arnold's confessing subject cannot be completely separated from the sexual and social subject, since sexual and social elements found their place in Cathar teachings, as well as in the teachings of other religious movements that clashed with the orthodox ecclesiastical ideas. In other words, Cathar theological dogma was not the only element of heresy that the official church wanted to destroy.

\subsection{Raymond de Laburat of Quié}

Raymond de Laburat was brought to inquisitor Fournier in February 1323 , when he confessed. Raymond's confession was heard because according to several testimonies Raymond spoke against the authority of the Church. Namely, the previous year Raymond was reported to the Inquisition by his namesake from the same region, Raymond Peyre. According to his statement, the accused spoke with several other men at the main place in Quié about the fact that several people from their region of Sabarthè were excommunicated because they had not paid the church tax. Supposedly, de Laburat stated: "we made churches for the churchmen and the church doors and now the same priests close the church door in front of our eyes... I wish there were a box in the fields and that the mass is celebrated on it, if thus was done, the priests could not close the doors in front of us, but we could hear it and see it". Raymond's monologue consisted of several more statements that offended the Church. Raymond believed that Fournier had no right to order the inhabitants of Quié to make an Easter candle of a certain weight, that he wished there were no clergy in the Sabarthè except one to hold the imagined mass in the fields, and

9 J. Arnold, Inquisition and Power, Philadelphia 2001, 12-13. 
that he wished the clergy to be ordered to work in the fields or to fight against the Saracens. ${ }^{10}$

Raymond's anger should be understood in an individual context and of social relations. Regarding the former, Raymond's fury at the church stems from the fact that he, along with several other people from the area, had been excommunicated due to non-payment of the church tithe, at Fournier's order. Raymond was angry at Fournier because he saw the bishop as the perpetrator of the changes in the social relations, maintained over decades if not centuries in this distant part of France. Raymond believed that the locals did not need to make the Easter candle because it had not been the custom before. It had also not been the custom that those excommunicated were forbidden from attending mass - this was a new custom introduced by Fournier. ${ }^{11}$ Seen from this aspect, his clash was not with a single man, who was the most efficient inquisitor of the time, but with the institution of the Church.

Raymond believed that the sinners were the churchmen because they sought to alter the old customs, which gave a type of security to the local shepherd population; they did not feel secure anymore since they could not behave according to the known rules. Fournier, as a member of the system of the inquisition, did not want them to perform according to the identified behaviour, which gave them a certain advantage. In this way, Fournier changed the rules of the game, or even canceled them and compelled the inhabitants to obey the strange principals, which seemed unregulated.

Raymond wished that he were with Fournier in a mountain gorge, known to him and the local inhabitants, where the two of them "would fight out the matter of carnalges [a measure of sheep meat that was given to the church], because I would see what the mentioned bishop has in his stomach". ${ }^{12}$ An imagined fight, as simple as the shepherd from the Pyrenees, would have maintained the old customs by the simple physical force, but the decentralized countryside with its ancient habits could not have resisted the change led by the larger world, which was irreversibly rushed towards centralization.

The commentaries of Raymond's case mention frequently that the shepherd desired a change in tripartite model of the feudal society, and which they see in Raymond's wish that the second estate - the church and the clergy - disappear from region. I believe that the matter concerns the wish to keep the existing local social order, to which changes, similar to modernization, have been made rapidly.

10 J. Fournier, II, 305-29, 305, 308-316; E.Le Roa Ladiri, Montaju, oksitansko selo 1294-1324, Novi Sad 1991, 271-2, 307.

11 Ibid., 310-314, 320.

12 Ibid., 324. 
Raymond defended himself emphasizing that all was said in anger, but the fact that he was one of a few accused who succeeded to draw Bishop Fournier in a debate on ecclesiastical matters testifies to the strength of his belief. For his wishful thinking, which offended the Church, but was far from Cathar theological dogma, Raymond was sentenced to penitence of strict prison, in irons and on bread and water.

\subsection{Beatrice de Planissoles}

Beatrice's case is one of the most frequently cited from Fournier's Register in studies on Catharism and the inquisition. ${ }^{13}$ Beatrice's case can be read as a case of a 'fallen woman', who was sentenced to penitence that was disproportionate to the committed transgression. Beatrice's confession can be taken as a particular erotic story, providing extremely detailed descriptions of her sexual practices and intimate life. Having been accused of saying that if the body of Christ (hostia) was as a big as a local mountain, it would have been eaten by then. Beatrice was cited before Fournier in June 1320. According to the Register, Beatrice was born in a family of lower nobility, of a father, who according to Fournier's accusations, was a follower of the Cathar teaching. Whilst married to her first husband, the castellan of Montaillou, she was unsuccessfully wooed by Raymond Roussel, her husband's steward. Roussel attempted to convince her to run away to him to Lombardy, where the Cathars still existed. Afterwards, whilst her first husband was alive, Beatrice was raped by Raymond Clergue, who kept "her publicly as his mistress". Not long after, she was seduced by Raymond's cousin, priest Pierre Clergue. The affair lasted for two years, when she married her second husband. After the death of the second husband, Beatrice started an affair with a priest, Bartholomew Amilhac, her daughters' teacher. ${ }^{14}$

Beatrice's confession demonstrates that her contact with heretical ideas was limited. Raymond Roussel urged her to leave her family behind, to devote herself to God (as understood in the heretical teachings) and go with him to Lombardy. Since she feared for her reputation, Beatrice refused. ${ }^{15}$ Pierre Clergue was another man who tried to impose the ideas upon her, which contained elements of the Cathar dogma. Clergue told her that it was irrelevant which men she had sexual relations with, that marriage meant nothing, and even that incest could be justified in certain cases, ${ }^{16}$ and when she fell gravely ill, during her second marriage,

13 Example: E.Griffe, 281; E.Le Roa Ladiri, 172-180, 184-188, 189; J. Arnold, (2001), 197-214.

14 J. Fournier, I, 218-222.

15 Ibid., 219.

16 Ibid., 224, 225. 
Clergue urged her to allow the Cathar prefect to administer consolamentum. $^{\text {17 }}$

Beatrice's confession can be interpreted in the context of the social norms of Languedoc, which were not innately influenced by Catharism, but which demonstrated influences of local pagan customs. This is the case with a piece of cloth drenched in the blood of Beatrice's daughter's first menstrual cycle, which was found on her when she was arrested, as well as the case with a herb that Pierre Clergue used to place on her stomach during their intercourse, in order to prevent her from conceiving. ${ }^{18}$

We shall never know whether Bishop Fournier was aware that hers was the case of a sinful woman, or he truly believed that she was a member of the Cathar movement. In any case, Fournier asked her specific questions that allowed him to connect her behaviour to the Cathar theological doctrine. Jean Duvernoy believes that Fournier's treatment of Beatrice demonstrates the intention of the Catholic Church to do away with social elements that were considered the centers of the local power. ${ }^{19}$ The penitence prescribed for the sins committed was carrying of crosses, whilst her young lover, the priest Amilhac was sentenced only to the recompensation of his sins.

\subsection{Arnaud de Verniolle}

The third is the case of a young sub-deacon, Arnaud de Verniolle, who was tried for heresy and sodomy. His case is mentioned in several types of medieval studies: from ones related to Cathar society and religion, to those that analyse medieval concepts of gender and sexuality. ${ }^{20}$ John Arnold also analyses his case in light of different contexts of the concept of sodomy between the inquisition and the accused in the medieval milieu.

Arnaud's case commences with the accusation by a student that Arnaud offered to hear his confession, although it was not in his jurisdiction, given his low status in the church hierarchy. Several days later three other students confirmed the original accusation. Arnaud was brought to Fournier, where he confessed that he impersonated a priest in order to hear students' confessions, as well as to sodomy. Arno's statement is filled with his personal understanding of what could be most widely defined as his concept of sodomy and most narrowly the act of sodomy. These can be seen from detailed descriptions of sexual acts with men, including the ones he carried out with the mentioned students, as well as

\footnotetext{
17 Ibid., 239, 234, 253-4.

18 Ibid., 252, 248, 244.

19 J. Duvernoy (1985), 35.

20 J. Paul, 26, 63.
} 
from the description of the process of seduction. ${ }^{21}$ It can be noticed from the Register that Fournier attempted to link Arnaud's confession about the homoerotic actions and his understanding of sexual practices, to the $\mathrm{Ca}$ thar teachings about sexuality and marriage. Thus, Fournier asks Arnaud if he told someone or believed that, since nature ordered him to quench his lust with either a man or a woman, it was not sinful to have relations with men or women. ${ }^{22}$ In a sense Arnaud's justification and explanation of his homoerotic practices was deemed heretical.

Arno was sentenced to a year in jail, after which he gave his complete statement with his sentence changed to life in prison and the removal of his ecclesiastical status.

Different opinions exist in historical analysis whether Arnaud was sentenced for heresy or for sodomy. The fact remains that his sentence was too high for the committed transgression. However, as it has been noticed, Fournier's sentences were not calculated based on the weight of the offense. If he managed to establish the existence of heresy, as constructed by him, and managed to bring the accused to confess, the leanest guaranteed penalty was wearing the crosses. Jacques Paul noted rightly that Fournier's penalties were far more severe than those passed by Bernard Gui in Carcassonne. ${ }^{23}$ The harshness of the punishments and the changes in the inquisition, which were incomprehensible to the locals, are not only a historical construction but were noted by contemporaries.

It seems that Arnaud did not comprehend that the rules of inquiry changed with Fournier, since throughout the process he was defending himself from the charges of sodomy, continuously referring to the consensual nature of the sexual relations that he pursued with the other men from his statement. ${ }^{24}$ In that Arnaud's reaction is similar to Beatrice's, who defended her honour rather than herself from the heretical ideas, and Raymond, who attempted to prove to the inquisitor that he had issues with the changes in social customs rather than spiritual dogma. Raymond was convicted for wishful thinking and not for the crime of heresy. Their mistake was that their quarrel was not with one man, but with the system that was becoming more rigid and which was being born together with a more centralized authority.

The earlier Manuals for inquisitors contained specific questions, which the accused had to answer. These were related to actions and the terminology used by perfecti and the contacts that the accused had with members of heretical sects. Fournier asked the accused to confess, which

\footnotetext{
21 J. Fournier, III, 14-50.

22 Ibid., 49.

23 J. Paul, 62.

24 J. Fournier, III, 39.
} 
meant talking about themselves and their pasts, ${ }^{25}$ which always contained an element of sin as misbehaviour, which allowed him to add to the actions deemed heretical, to the extent that thoughts became a regulated area. It is within this gap between the old judicial system and the new, more complex system of the inquisition that the surprise of those convicted needs to be viewed. When one prisoner heard that an inmate had been punished only for what the former thought had been said in anger, he exclaimed that he had never heard that the inquisitor at Carcassonne (unlike Fournier in Pamiers) condemned anyone for words said if those had not seen the heretics. ${ }^{26}$ Fournier's contemporary's opinion stands in contrast to that of a famous historian of Catharism, Elli Griffe, who believes that Fournier's sentences might have been harsh, but were in line with the spirit of the time. ${ }^{27}$ Some contemporary members of the clergy believed the trials to be both unfair and staged, to such an extent that even Peter and Paul would have been condemned. ${ }^{28}$ As Irene Bueno noticed, Fournier's inquisitorial way meant a clean cut from previous practices, where dogma played a small role and the official respect of the sacrament represented the distinction between heresy and orthodoxy. He sought to extend heretical paradigm, by introducing new elements that were followed in the courts as wrongdoings. ${ }^{29}$ Such an inquisitorial manner was made possible by the lack of sense of guilt - the intention to for commit delict was no element of guilt. ${ }^{30}$ The cultural difference between Fournier, the doctor of theology from the Paris University, and inhabitants of the Pyrenees is undeniable.

\section{CONCLUSION}

The absence of an organized heretical movement in Languedoc led Fournier to prosecute acts that had not been considered characteristically heretical. Transgressions were linked to elements of Cathar teachings, whose ideas of sexual freedom of both sexes and noH-acceptance of marriage were known to the inquisitors. This enabled construction of a heretical identity from the offending identity. Through this processes the French inquisition isolated behaviours and contextualized them as dan-

25 John H. Arnold emphasizes this in definition of the confession and employs it in when talking of the construction of the confessional subject.

26 J. Duvernoy (1985), 47.

27 E. Griffe, 281-283.

28 A. Friedlander, The Hammer of the Inquisitors, Leiden 1999, 49; J.Arnold, "Inquisition, Texts and Discourse", Texts and the Repression of Medieval Heresy (eds. C. Bruschi, P. Biller), New York 2003, 64.

29 I. Bueno, Defining Heresy Inquisition, Theology, and Papal Policy in the Time of Jacques Fournier, Leiden 2015, 112, 119.

30 J. Duvernoy (1985), 47. 
gerous, deviant, 'other', i.e. heretical, and managed to have a positive influence in the process of very early centralization of France. Fournier succeeded in creating a judicial court system that was almost impossible to leave the accused unpunished, i.e. they had to repent their sins, thus becoming a member of marked sub-group.

\section{REFERENCES}

Arnold, J., Inquisition, and Power. Catharism and the Confessing Subject in Medieval Languedoc, Philadelphia 2001.

Arnold, J., "Inquisition, Texts and Discourse", Texts and the Repression of Medieval Heresy (eds. C. Bruschi, P. Biller), New York 2003.

Bueno, I., Defining Heresy Inquisition, Theology, and Papal Policy in the Time of Jacques Fournier, Leiden 2015.

Duvernoy, J., "Le Catharisme en Languedoc au début du XIVe siècle", CdF 20/1985.

Duvernoy, J., "La Procedure de Repression de l'Heresie en Occident au Moyen-Age", Heresis 6/1986.

Friedlander, A., The Hammer of the Inquisitors: Brother Bernard Délicieux and the Struggle Against the Inquisition in Fourteenth-Century France, Leiden 1999.

Given, J., "The Inquisitors of Languedoc and the Medieval Technology of Power", The American Historical Review 94(2)/1989.

Given, J., Inquisition and Medieval Society. Power, Discipline, and Resistance in Languedoc, Ithaka 1997.

Griffe, E., Le Languedoc Cathare et l'Inquisition, 1229-1329, Paris 1980.

Guidonis, B., Practica inquisitionis heretice pravitatis auctore Bernardo Guidonis (ed. C. Douais), Paris 1886.

Gui, B., Manuel de l'inquisitor, 1-2 vols. (ed. and transl. G. Mollat), Paris 7/1926.

Le Roa Ladiri, E., Montaju, oksitansko selo 1294-1324, Novi Sad, 1991.

Le Registre d'inquisition de Jacques Fournier, évêque de Pamiers, 13181325: manuscrit Vat. latin $n^{\circ} 4030$ de la Bibliothèque vaticane (with the introduction and the notes by Jean Duvernoy), Toulouse $3 / 1965$.

Moor, R. I., The Formation of a Persecuting Society, Oxford 2007.

Paul, J., "Jacques Fournier inquisiteur", $C d F$ 26/1991.

Article history: Received: 23. 9. 2017. Accepted: 27. 11. 2017. 